\title{
Temporal analysis of urban changes and development in Warsaw's ventilation corridors
}

Abstract

This paper presents the results of the urban indicators analysis conducted within Warsaw's ventilation corridors from 1992 to 2011. The literature review shows that the Floor Area Ratio (FAR) index is one of the best indicators to detect urban development; therefore, this was the core of the analysis. Three periods were analysed (1992-2002-2011), as such a long time-span allows the assumption that change will be visible. The ventilation corridors were divided into $500 \mathrm{~m}$ and $100 \mathrm{~m}$ grids and the FAR index was calculated for each cell. The results highlight alarming changes within some of the corridors, indicating areas that are crucial to sufficient air flow in Warsaw.

Keywords

Spatial analysis $•$ GIS $•$ FAR $\bullet$ floor area ratio $\bullet$ urban climate $\bullet$ ventilation corridors

(c) University of Warsaw - Faculty of Geography and Regional Studies

\author{
Marzena Wicht, Katarzyna Osińska-Skotak \\ Department of Photogrammetry, \\ Remote Sensing and Geographic Information System \\ Warsaw University of Technology \\ e-mail: mwicht@gik.pw.edu.pl \\ Department of Photogrammetry, \\ Remote Sensing and Geographic Information System \\ Warsaw University of Technology \\ e-mail:k.osinska-skotak@gik.pw.edu.pl \\ Received: 10 August 2016 \\ Accepted: 17 November 2016
}

Introduction

The urban climate has a profound impact on a city's inhabitants, as well as on its spatial planning and development (Goldberg, Kurbjuhn \& Bernhofer 2013). High density living, lack of green areas, increasing air pollution and urban heat islands are just some examples of the issues that city planners and managers are confronted with ( $\mathrm{Ng} 2006)$. Regarding the massive pressure of the growth of urban areas on the environment, appropriate management of the city-ecosystem is without doubt an essential part of modern city planning. What is more, for the first time, more than half of the human population is living within urban areas (Heilig 2012). By 2030 this number will have risen to almost 5 billion, with urban growth concentrated in Africa and Asia (United Nations 2007). While mega-cities have caught much public attention, most of the future growth will occur in smaller towns and cities, which have fewer resources to respond to the magnitude of the change (United Nations 2007). To manage such a complex organism as the city climate itself, many ideas have been raised over the years (Bożętka 2014): the idea of the Garden City, green belts, reintroducing green corridors along streams or on conversion areas, and so on. These areas can provide air restoration and decrease air pollution; thus, proper administration and governance can assure proper management of the city's climate.

The swelling tendencies of cities have been noticed since early industrialisation, when people started to congregate in cities en masse. Dense, dirty and polluted cities and their poor sanitary conditions (such as the cholera outbreak in London in 1854) attracted the attention of city planners. One of the first approaches to tackle this issue was Ebenezer Howard's book 'Garden Cities of Tomorrow', published in 1902 (Ebenezer 1902). The proposed Garden City was not meant to be a suburb but its antithesis - not a place to escape from the city, but an integrated unit of efficient, healthy and enjoyable human life. It did not destroy the traditional perception of residence, but it expressed the economic and climatic advantages of living outside the compact urban structure. The high popularity and large number of supporters opened up a new 'chapter' in city planning, which we use today to define settlement systems called urban agglomerations. Such cities or districts merge all the advantages of living in cities (work, technical and social infrastructure) with the qualities of countryside living - each unit was properly ventilated due to vast vegetation areas. There have been many developments influenced by the Garden City movement - both in Poland (Sokołowska-Moskwiak 2011; Solarek 2011) (inter alia some Warsaw districts (Gzell, Soltys \& Tatarkiewicz-Nawrocka 2002)) and internationally (Buder 1990; Alanen 1992; Culpin 2015). Unfortunately, the size of $\sim 2,500$ ha needed for its realization to accommodate only 35,000 inhabitants was not the final answer. The second half of the $20^{\text {th }}$ century brought 'sustainable development in cities'. It has been referred to as a priority at many international conferences (Johnson 1993) and urban green areas have been designated to play a crucial part in shaping urban ecosystems. Their unique feature is a combination of objects shaping green urban areas, which have long been included in the structure of the city (primarily parks and gardens), along with the elements which have been incorporated into the system relatively recently, such as the marginal zone (suburbs) and ecological corridors reaching far beyond the city (Bożetka 2014). The implementation and management of connected 
green urban areas has already happened, for instance in Berlin (Drapella-Hermansdorfer 2005) and London (Amati \& Yokohari 2006). The plan written by Patrick Abercrombie in London after World War II assumed that introducing 'green belts' (a continuous system of green areas) would help to prevent urban sprawl as well as having a positive impact on the city's climate (temperature, humidity) and air pollution (Gant, Robinson \& Fazal 2011). Nevertheless, even such actions did not prevent weather/climate change from proceeding. London, alongside many other megacities, suffers from a dense urban structure and its effects, such as Urban Heat Islands (Han, Mun \& Huh 2007). One of the ways to fight these effects is by attempting to introduce 'ventilation patches' or 'corridors' in order to bring air flow to the city.

\section{City climate and ventilation corridors}

Urban heat islands

The Urban Heat Island (UHI) is a widely researched phenomenon (Han, Mun \& Huh 2007; Rizwan, Dennis \& Chunho 2008; Hamdi \& Schayes 2008) and refers to the temperature difference which occurs between a city centre and its suburbs or adjacent non-urbanized areas. As more areas become urbanized (United Nations 2007), the natural environment and local eco systems are immensely affected and they lose their vital balance (Rizwan, Dennis \& Chunho 2008). Due to heat release from power plants, cars and massive urban structures (which have different thermal properties (Hamdi \& Schayes 2008)) and a lower proportion of land use for vegetation, large cities are particularly vulnerable to the negative effects of UHI.

Rizwan, Dennis and Chunho reviewed many mitigation measures, such as using building materials with high albedo, proper building design or planting more vegetation. They also stressed that mitigation efforts can lead to significant power savings, decreases in annual carbon use and reductions in the temperature difference. Other researchers ( $\mathrm{Ng} 2006$; Ghiaus et al. 2006; Ng 2009; Mirzaei \& Haghighat 2012; Suder \& Szymanowski 2014) have suggested that deriving and preserving connected areas of low roughness might contribute to the air ventilation and exchange system, therefore mitigating the UHI effects. Such areas, called ventilation corridors, enable air to flow with less resistance than it would encounter while flowing through densely built-up areas. These specially designated areas supply the city with clean air and discharge the fumes and polluted air.

\section{Urban green areas}

Urban green areas fulfil important functions in shaping urban space, especially in large cities and their surroundings. Among the many functions, a few can be distinguished which have particular significance for a city's climate and the supporting natural environment: Habitual (soil production, chemical element circulation), Supplying (food, water and fossil fuels), Regulating (climate, purification of soil, water and air, neutralization and decomposition of waste) and Cultural (tourism, education, sport and recreation, relaxation) (Kronenberg \& Łódzki 2012). Depending on the scale of research or the nature of the studied ecosystem, we can either state that a city is an ecological system (as a whole) or a combination of ecological systems (Bożętka 2014). The areas that are included in the urban ecosystem rarely 'form unities', which means they are continuous across the whole city. Usually, their location and shape is a reference to the urban composition and they should be related to the adjacent green areas and green corridors reaching the suburbs. Unfortunately, this is not a common practice for strengthening outside the city's administrative boundaries, so any green corridor beyond the city's limits may not be extended. There are exceptions, however, when international ecological corridors occur (Bożętka 2014).
Urban green areas are also not defined clearly and their interpretation differs from country to country and from author to author. Some define them as 'an entirety of non-built up areas' (Giedych 2005) and some count 'parks, boardwalks, boulevards, botanic and zoo gardens, graveyards and green areas adjacent to streets, public squares, buildings, airports as well as industry and areas designated to railroad infrastructure' (Bożętka 2014). Apart from those mentioned above, meadows, pasturelands, forests and even farmlands are also classified as green areas and they are all found in cities to some extent, and are therefore enlisted to urban green areas.

Some of these green areas could be used as ventilation corridors. Provided there are areas of significantly low roughness properties, they are connected to each other and supply clean and cooled air from the suburbs or adjacent open areas; these can be labelled air exchange and restoration systems. If they also penetrate the inner city with a country breeze, and therefore decrease the urban-rural contrast in temperature, they are called ventilation corridors (Gál \& Unger 2009). These are characterized by many aerodynamic features and their geometry and surface are best described by their roughness parameters (Davenport et al. 2000; Gál \& Unger 2009).

\section{Ventilation corridors in Warsaw}

The designation of Warsaw's ventilation corridors dates back to the early $19^{\text {th }}$ century, when the need for the proper management of green areas was noticed. However, early attempts focused on the prevention of settlement spread (Królikowski \& Ostrowski 2009). Different development and management plans mentioned the need to preserve green areas in the city, including for use as ventilation paths. In the development plan for Warsaw introduced in 1938, the term 'ventilation corridors/paths' occurs for the first time, together with their designation and dimensions (Jankiewicz \& Porębska-Srebrna 2006). The period after World War II was unfortunately poorly managed (urban planning-wise) due to the complicated political situation in Poland. The time directly after the war was dedicated to Warsaw's restoration (Smętkowski 2009) and later, during the communist period, planning focus was shifted away from many brilliant pre-war ideas (such as i.e. ventilation corridors, metro lines or suburban train system). Therefore, green areas (ventilation corridors included) were not given particular interests in favour of socialist buildings and monuments. The initial concept of air regeneration and ventilation system in Warsaw, which task was to facilitate the horizontal air exchange through the city and enabling free air flow from remote (suburb) areas to the city centre, was founded in the mid-1970s. This system was an addition to the natural ventilation path of the Vistula valley. The system of corridors was designated considering wind direction, topography, land use and planned development. Unfortunately, its functionality has not so far been the subject of a comprehensive study. The system was gradually diminished, as a result of the proceeding expansion of the Gocław, Bemowo, Targówek and Białołęka districts. Moreover, each successive development plan reduced its area. The legally binding records regarding management of the system became more and more liberal, which resulted in the introduction of buildings and reduction of the green areas within it. The first proper step towards protecting them was their designation within the general development plan in 1992 (Rada m.st. Warszawy 1992). After the political system change, development plans respected property rights, which significantly influenced their outcome. For the first time after WWII (1989 to be exact) planning and ground properties were open to the free market, which made it almost impossible for the local authorities responsible for urban planning to predict the dynamic of the change as well as the pressure coming from private investors and developers. Nevertheless, some ideas and actions presented in 
this document have changed the modern landscape of Warsaw and are still visible today. For example, ventilation corridors were included in a large part of the plan, called the 'Air regeneration and ventilation system'. The system was supposed to sustain the climate (at least not to deteriorate it and, if possible, to improve it) and to ameliorate living conditions in Warsaw.

The air exchange and regeneration system in Warsaw established in the general development plan (Rada m.st. Warszawy 1992) (legislated in 1992), was reinforced in a comprehensive study of conditions and directions for the spatial development of Warsaw in 2006 (SUKiZ) (Rada m.st. Warszawy 2010). Since 2003 (when spatial development legislation changed), studies usually covering whole municipalities (Warsaw, due to its size is regarded as such) have been less binding and site plans which cover, for instance, a housing estate, have to apply the indications of the municipality studies. When preparing the study in Warsaw, the local government commissioned a comprehensive study to designate an air regeneration system in order to include its results in the study. It confirmed the concept established in 1992 and recognized 9 ventilation corridors (see Figure 1) (Rada m.st. Warszawy 2010):

1. Vistula River Corridor-occupies the entire area of the Vistula in Warsaw and its river bank. Its importance in Warsaw's air exchange system is huge - it supplies clean air to the central part of the city and disposes of contaminated air outside its borders (to the north and south). The high grade of ventilation determines the significant proportion of water surface, meadows and agricultural land. More than half of this corridor is occupied by areas characterized by good ventilation. Other areas - forests and riparian woodlands, recreation areas and parks - also have a great importance for air regeneration. Until now, the functionality of the corridor has remained undisturbed, although intensifying the settlement of Gocław district and thus narrowing the corridor has clearly weakened the intensity of air exchange in the centre. This is particularly noticeable in the summer.

2. Bródnowski Corridor - runs through Białołęka and Targówek along the Nieporęcka stream. The clean air supply areas are Nieporęt and Legionowo forests, and the meadows and agricultural land in the municipalities of Nieporęt and Marki. Again, more than half of its areas are good ventilation areas. The significant proportion of the land covered by high vegetation determines the advantage of the regenerative function of air exchange, rather than an air-flow function. Due to the low frequency of winds from the north and northeast, this corridor plays an important role on a local scale - especially during the spring and summer - whilst its role in the citywide system is smaller.

3. East Railway Corridor - even though it runs along the railways, through industrial areas, the importance of its functionality for the air exchange system in the city is significant. Due to the barrier created by the high vegetation of the Rembertów-Otwock forests, open railway areas play a large role in supplying the city with high quality air.

4. Wilanowski Corridor - runs with the lowest left coast terrace of the Vistula - along Wilanówka Valley and the oxbow lakes, Lisowskie Lake and Czerniakowskie Lake. This corridor brings the southern winds to the city and, together with the Vistula corridor, it plays a fundamental role in regenerating and ventilating the city. The functioning of the corridor together with the Vistula corridor is determined by existing land development: a lot of low intensity buildings and a considerable proportion of pervious surfaces as well as recreation areas.

5. Podskarpowy Corridor - runs along the southern part of the Warsaw escarpment, covering its slopes. This is a corridor with a very significant and specific role in the city's air exchange system, as it brings clean air masses from the south. However, its most important function is discharging heated and polluted air coming from Warsaw's 'left coast'.

6. Mokotowski Corridor - starts with the wide strip of undeveloped land around Okęcie Airport and stretches north, running through the Ursynów, Włochy, Mokotów and Ochota districts. The air flow within this corridor is the most disturbed due to progressive development (EkoPark, Marina Wyględów estate and Fort Mokotów). The functionality of this corridor may still be possible, unless more built-up areas are introduced.

7. Jerozolimski Corridor - runs through Ursus and Ochota districts, along the southeast edge of Jerozolimskie Alley. The corridor has a favourable course in the direction of relatively frequent south-west winds. It transfers air masses from the Sękocin and Nadarzyn forests and from above the agriculture land in the Michałowice region. The functioning of the corridor is disturbed by low-rise multi-family and single-family housing, as well as the commercial and service buildings along Jerozolimskie Alley. The prerequisite for its further functionality is to prevent new development.

8. West Railway Corridor - shaped in a strip of land occupied primarily by railway buildings and devices, characterized mainly by favourable conditions for the ventilation of the city, in which it aids the Bemowski corridor. However, it plays a smaller role in air regeneration. Given the significant proportion of winds from the west and their role in the air exchange, areas within this corridor should remain unchanged.

9. Bemowski Corridor - stretches across the Bemowo, Wola and Żoliborz districts. Its location is favourable in terms of the wind directions (east-west) and it is connected to Forest Park Bemowo and the primeval Kampinoska forest, which supply clean air for the city. Due to large proportion of high vegetation, only the old airport and recreation areas are characterized by good air flow. It plays an important role in the city air exchange system because of the high quality air supplied within it, although the air flow itself is obstructed. The recent developments in the vicinity of the airport have made the air flow corridor even narrower, making it no more than a 'stream'. Its functionality will be preserved by restraining further development. Otherwise, considerable disturbances may be caused in the supply of clean air to Żoliborz district and the city centre.

As mentioned above, in 2006 SUKiZ reinforced the idea of ventilation corridors and emphasized the necessity of protecting them in order to preserve the air regeneration and ventilation processes in Warsaw. It clearly states the maximum height allowed, which, with few exceptions, varies from 12 to $15 \mathrm{~m}$. However, the areas preserved for this purpose significantly diminished between 1992 and 2006 (Zawalich 2012). The analysis of these two documents shows a negative change - the area of ventilation corridors was diminished by $13 \%$ in total. This may be connected with the common perception of the Polish spatial planning system which tend to adjust to the existing reality rather than shape it (Zawalich 2012). The analysis has also shown that only $23 \%$ of the air regeneration system is covered with binding site/development plans. Moreover, even those development plans allow, in numerous cases, heights above those established in SUKiZ. Examples of this can be found in the Mokotowski corridor, where the binding development plan allows buildings up to $25 \mathrm{~m}$, or the Bródnowski corridor where it allows multifamily buildings up to 13 storeys. One of the most disturbing examples of the lack of cohesion between SUKiZ and the binding development plans 


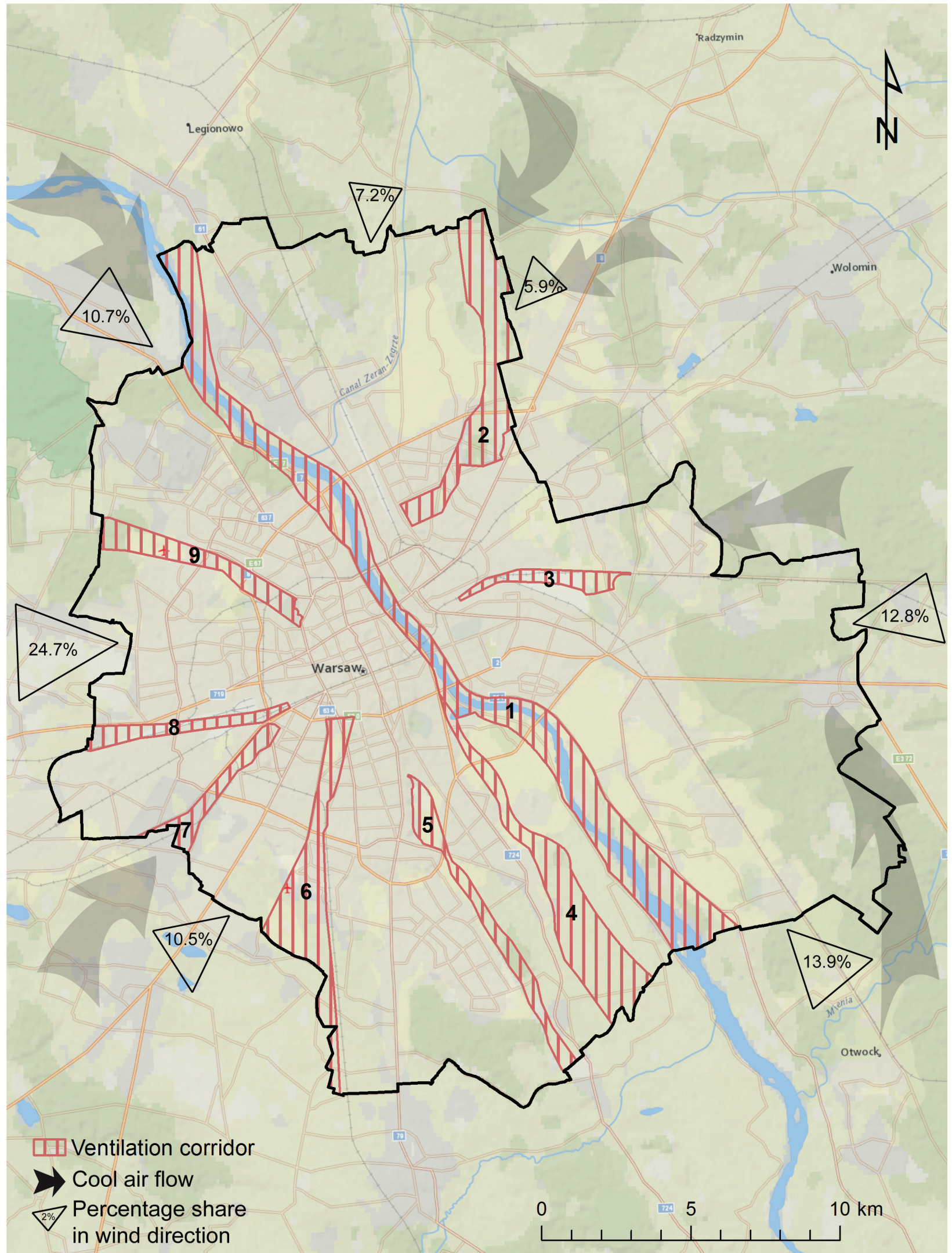

Figure 1. Ventilation corridors in Warsaw, Source: own study based on Warsaw's SUiKZ 
occurs in the Podskarpowy corridor (Zawalich 2012) - for most areas the plan allows building up to $11 \mathrm{~m}$, whereas in the most narrow opening it permits buildings up to $25 \mathrm{~m}$ (Rada m.st. Warszawy 2008).

\section{Methodology}

In the open countryside, the climate depends largely on natural conditions, such as the latitude, the altitude above sea level, the amount of sunlight, and so on. In urban and industrial landscapes, in opposition to the surrounding countryside, we find an altered local climate, the so-called urban climate. There are many thresholds describing the spatial characteristics (Samimi \& Strobel 2003; Mayer, Beckröge \& Matzarakis 1994; Han, Mun \& Huh 2007) of ventilation corridors, but one feature they all have in common is the minimum width of $500 \mathrm{~m}$, which should enable air flow. Therefore, two grid sizes were taken into account $-500 \mathrm{~m}$, as a threshold for width, and $100 \mathrm{~m}$, to detect subtler changes. As a reference area, ventilation corridors from SUKiZ were used, as these borders are the most up-to-date, law-abiding boundaries.

The aim of this study was to detect and analyse the development change within ventilation corridors for three periods: $1992-2002-2011$. This almost twenty-year period allows the assumption that change will be noticeable. Since overall urban development has the most significant effect on air flow and circulation, change in the floor area ratio was analysed. The floor area ratio is the sum of the total floor area in a building divided by the area of the land on which it is built (Kono, Kaneko \& Morisugi 2010). Floor area ratio (FAR) is widely used in urban planning (Joshi \& Kono 2009; Gao et al. 2006; Feng 2009) and is most commonly the ratio for a single allotment or a piece of land determined by a binding site/development plan. Thus a reference area had to be chosen that was neither too detailed, nor emitting important information.

The FAR index and density of development index are the key indicators of urban characteristics that indicate the level of land use development (Handy et al. 2002; Jiang et al. 2007). However, used alone, they do not provide sufficient information about the spatial characteristics and standards of developed areas, and consequently do not describe their qualities as a place to live. The FAR index also expresses the efficiency of commercial land use of the single allotment: the approximate size of the usable area of investments obtained per $1 \mathrm{~m}^{2}$ of land. This indicator is often used by developers, as a simple tool to assess the viability of the investment. The FAR index tells us little about how the allotment is being used. Only additional information - like the height of the buildings (WMNS - the weighted mean number of storeys) or density of development (the ratio of the developed area to the allotment area) - allows the characteristics of the area to be seen better (Dabrowska-Milewska 2010b). However, calculating WNMS for ventilation corridors alone would not reflect the characteristics of Warsaw's buildings. A complex analysis, for the whole city might reveal certain patterns in terms of legal and framework changes in urban development (Dabrowska-Milewska 2010b). Also, in our future research, we plan to investigate different approaches to the analysis of ventilation corridors, such as the high resolution mapping of roughness parameters presented in Gál and Unger, or the frontal area index and least cost path analysis, as executed by Wong, Nichol and $\mathrm{Ng}$.

In order to calculate the FAR index, certain attributes of a $3 \mathrm{D}$ building geodatabase are required. The spatial cadastral database for the whole city was acquired from the city council, dating from March 2011. The attributes highlighted included the number of storeys, function, district and topicality. Unfortunately, the cadastral database was not available for the previous decades. Therefore, high resolution satellite imagery (Systéme Pour l'Observation de la Terre/High Resolution Visible and
Infrared - SPOT) was acquired for 10 September 1992 (SPOT $210 \mathrm{~m}$ resolution, pansharpened), 12 September 2002 and 26 August 2011 (both SPOT $52.5 \mathrm{~m}$ resolution, pansharpened) as base data. The most up-to-date building footprints extraction is based on VRH optical satellite imagery aided by LiDAR data (Wurm et al. 2009). Here, however, the challenge was to derive reliable information from high spatial resolution $(2.5-10 \mathrm{~m})$ multispectral imagery acquired from SPOT satellites. As vegetation might have proven to reduce the quality of deriving the building outlines, the NDVI (Normalised Differenced Vegetation Index) was masked and removed from further processing. Object-based image analysis (Blaschke 2010) and segmentation was conducted to derive the building footprints. As mentioned above, we were in possession of the building database for 2011, which was then used in an initial segmentation level and later to smooth the edges of the objects as well as deriving attributes. Further classification was conducted with the aid of SVMs (Support Vector Machines). The resulting outlines where subsequently simplified and all remaining artefacts erased. This led to the creation of 3 building databases for 1992, 2002 and 2011, consisting of 114,828, 123,368 and 153,595 objects, respectively. In order to derive the height attribute, we used the existing database for 2011. It was then assumed that buildings existing in 2011, if proven to have been already built in 1992, maintained the same height. For any buildings that were not discovered in the database in 2011, a manual analysis of the neighbourhood and a shadow length analysis were performed in order to assess building height. Naturally, the biggest challenge was to extract the outlines from SPOT from 1992 - the pansharpened image had a resolution of $10 \mathrm{~m}$, which made it particularly difficult with some smaller dwellings, such as (semi-)detached houses or villas. Therefore, creating a building database for 1992 was the longest and most laborious part, as many buildings had to be added manually. The resulting databases of Warsaw's buildings for the three periods were then cross-referenced with the ventilation corridors, which were first adjusted to the $500 \mathrm{~m}$ or $100 \mathrm{~m}$ grid. The first part of FAR, namely area $(A)$ of the building multiplied by number of floors (NoF) ( $A$ * NoF, see Figure 2), was then calculated based on the attributes available within the database. Once computed, values were attached to each tile and FAR was calculated as the ratio of the sum of the previously calculated value $(\Sigma A * N o F \rightarrow$ gross floor area (GFA)) within each tile to the respective tile area.

Once FAR has been computed, the result was analysed. The first step was to analyse the index and its change between each period. It was decided to divide areas into $500 \mathrm{~m}$ and $100 \mathrm{~m}$ tiles. For the $500 \mathrm{~m}$ grid, the ventilation corridors were divided into 630 tiles, with areas ranging from $0.044884 \mathrm{~m}^{2}$ to $250,000 \mathrm{~m}^{2}$. This large range was caused by the division of corridor shapefiles, which are irregular in shape, into a regular grid. Each period was analysed separately and then unified by the FAR index with the biggest values, namely from 2011 . Range classes were derived based on the automatic natural breaks classification scheme, which creates breaks based on natural groups in the data distribution. They appear in the histograms at the lowest points of data valleys. Breaks are appointed depending on the size of valleys, with the largest valley assigned to the first natural break (Esri 2014).

For the second step of the analysis, the decision was made to perform the analysis again, but to reduce the grid size to 100 $\mathrm{m}$ in order to identify subtler changes. The ventilation corridors were divided into 9,707 tiles with areas varying from $0.003436 \mathrm{~m}^{2}$ to $10,000 \mathrm{~m}^{2}$ ( $1 \mathrm{ha}$ ). Again, the FAR values from the three periods were classified according to the biggest possible value.

Once computed, the FAR values were analysed for each grid size. 


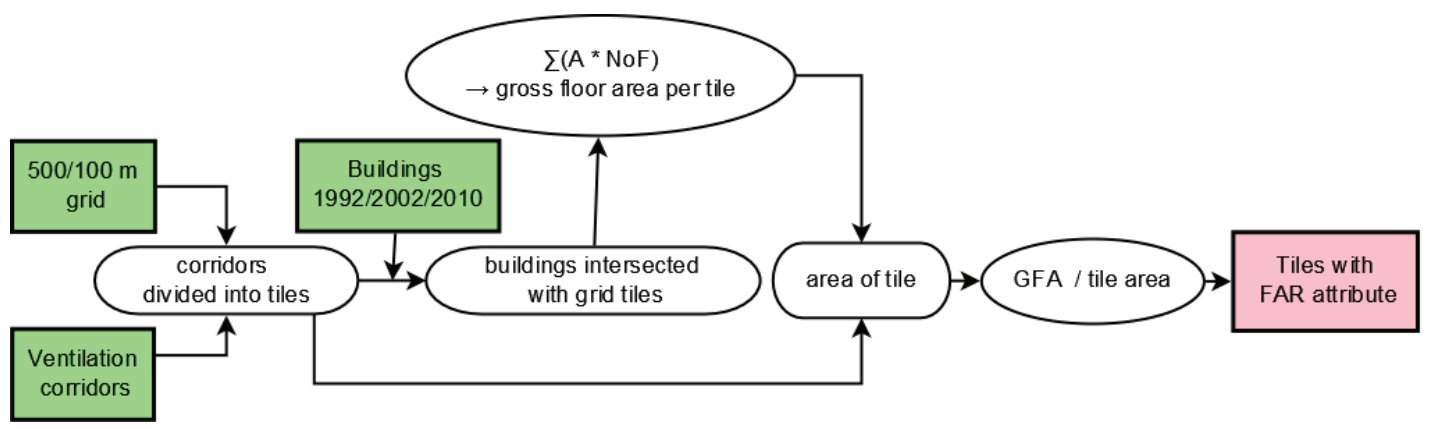

Figure 2. FAR calculation process, Source: own study
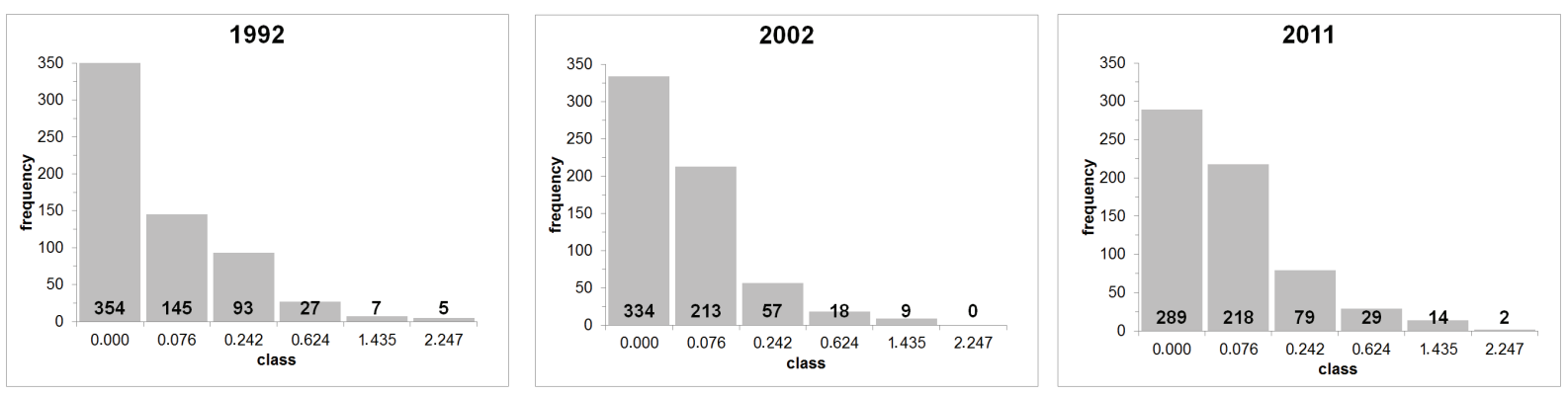

Figure 3. Frequency distribution of FAR values for $500 \mathrm{~m}$ grid, Source: own study

Results

The results for the $500 \mathrm{~m}$ grid and the distribution in each class are presented in Figure 3 and Table 1.

According to the results, the biggest FAR index values occur in 2011, and the number of tiles with a value of zero (which means that no change occurred) decreased. Moreover, the highest number of tiles with a FAR index of more than 0.25 (which means $25 \%$ intensity) was also seen in 2011. A maximum value of 2.2 is commonly seen among development plans for urban areas, but not when green/open areas are discussed. A comparison of FAR index values between each period was also performed and clustered spatially into corresponding corridors (see Table 2.)

The percentage change in Table 2 represents the proportion of tiles that changed between the two dates. It does not give any information about the quality of the change, which is given by the maximum values and average change values.

Accordingly, the biggest change (in terms of area) between 1992 and 2002 occurred in the Jerozolimski corridor (almost 70\% of its tiles changed their values). What is more, the mean value of all changes is quite significant - it is the third biggest value. In addition, the maximum value of change within this corridor is the second largest. A slightly bigger change occurs only in the Bródnowski corridor. However, the fact that, within this corridor, only $9 \%$ of all tiles changed should not be overlooked - this indicates rapid but concentrated urban development. A similar situation occurs in the Vistula River corridor - although the change covers only $6 \%$ of all tiles, the mean change value is significantly high in comparison to the other corridors, as is its maximum. The change within the West Railway corridor is also worth mentioning. Even though almost $30 \%$ of its tiles changed between 1992 and 2002 , the mean and maximum values are relatively low. Thus, a gradual and slight change can be detected. The reason for this lies partly in the characteristics of this particular corridor -
Table 1. Frequency distribution of FAR values for $500 \mathrm{~m}$ grid

\begin{tabular}{|c|c|c|c|}
\hline Range values & $\mathbf{1 9 9 2}$ & $\mathbf{2 0 0 2}$ & $\mathbf{2 0 1 1}$ \\
\hline 0 & 354 & 334 & 289 \\
\hline $0.001-0.076$ & 145 & 213 & 218 \\
\hline $0.076-0.242$ & 93 & 57 & 79 \\
\hline $0.242-0.624$ & 27 & 18 & 29 \\
\hline $0.624-1.435$ & 7 & 9 & 14 \\
\hline $1.435-2.247034$ & 5 & 0 & 2 \\
\hline
\end{tabular}

Source: own study

as a railway corridor, most of its area is occupied by railways and buildings connected with this infrastructure, so little change occurs there.

The analysis of the next period (2002-2011) highlighted that the biggest changes in terms of area occurred within the Jerozolimski corridor, and its maximum value is the second highest. The biggest increase in FAR value was appointed to the Mokotowski corridor, as was the biggest mean value, even though only $44 \%$ of its tiles changed. This may point either to one larger, clustered change or a few, spread changes. The biggest increase in FAR value occurring within this corridor is consistent with the rapid urban development of this district at the time. The lowest maximum FAR change value was detected within the East Railway corridor. Like the West Railway corridor, it is mostly occupied by railways; therefore, little change occurs there. This is also the reason that only $23 \%$ of the tiles changed. However, a lot of change occurred within the West Railway corridor during 
Table 2. Statistical FAR change between each period, Source: own study

\begin{tabular}{|c|c|c|c|c|c|c|}
\hline \multirow{2}{*}{$\begin{array}{c}\text { No. } \\
\text { (corridor) }\end{array}$} & \multicolumn{3}{|c|}{$1992-2002$} & \multicolumn{3}{|c|}{$2002-2011$} \\
\hline & $\%$ change & mean & $\max$ & $\%$ change & mean & $\max$ \\
\hline 1 & $6.05 \%$ & 0.185 & 0.954 & $22.33 \%$ & 0.034 & 0.294 \\
\hline 2 & $9.64 \%$ & 0.162 & 1.078 & $45.78 \%$ & 0.123 & 0.842 \\
\hline 3 & $14.29 \%$ & 0.008 & 0.022 & $23.81 \%$ & 0.012 & 0.030 \\
\hline 4 & $10.59 \%$ & 0.012 & 0.055 & $40.00 \%$ & 0.020 & 0.145 \\
\hline 5 & $9.80 \%$ & 0.006 & 0.015 & $49.02 \%$ & 0.017 & 0.114 \\
\hline 6 & $16.00 \%$ & 0.030 & 0.185 & $44.00 \%$ & 0.180 & 2.247 \\
\hline 7 & $67.74 \%$ & 0.149 & 1.057 & $74.19 \%$ & 0.159 & 2.082 \\
\hline 8 & $29.63 \%$ & 0.054 & 0.284 & $70.37 \%$ & 0.010 & 0.115 \\
\hline 9 & $11.90 \%$ & 0.145 & 0.326 & $40.48 \%$ & 0.012 & 0.089 \\
\hline
\end{tabular}
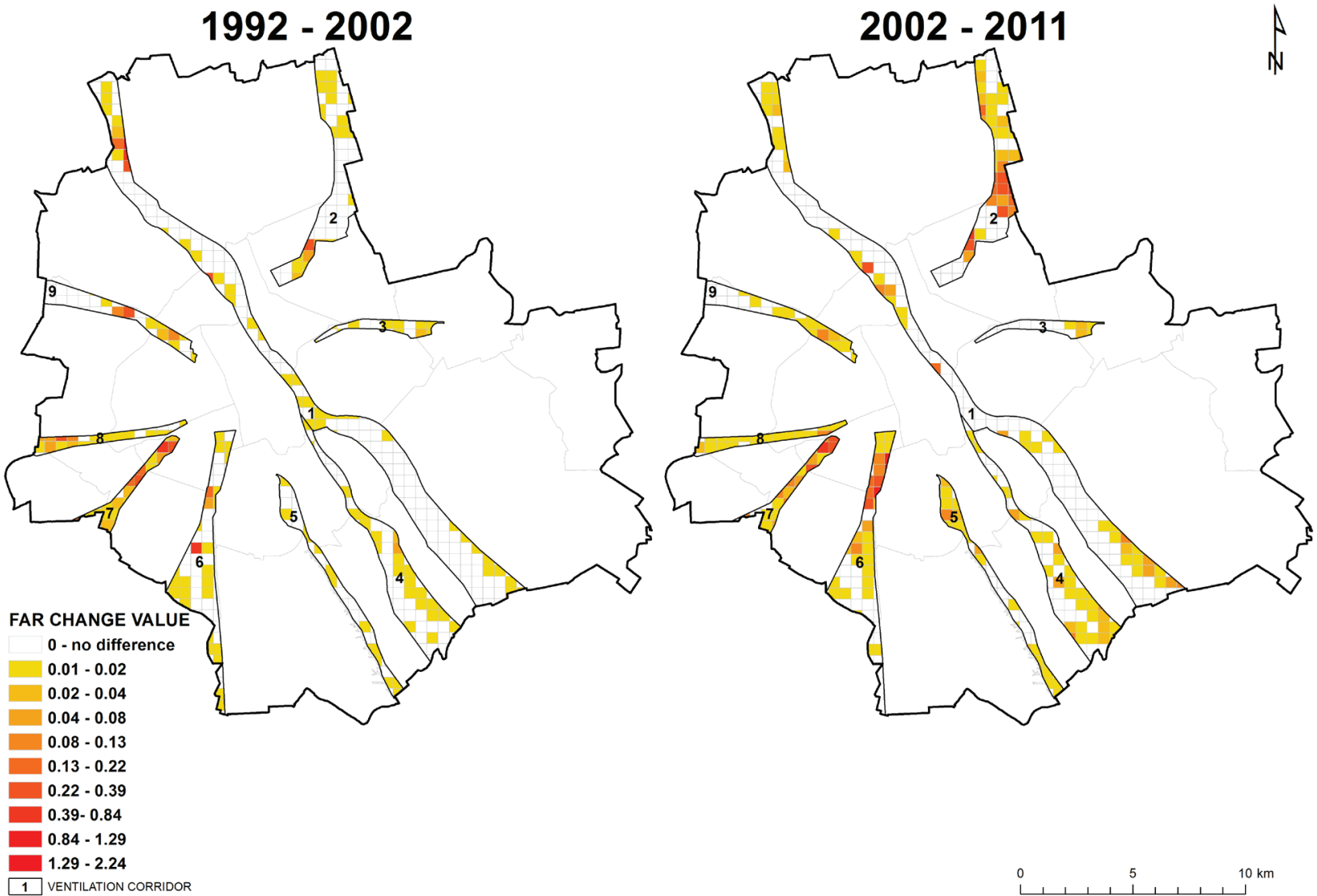

Figure 4. Spatial distribution of FAR changes in 1992 - 2002 and 2002 - 2011 for 500 m grid, Source: own study

this period - more than $70 \%$ of its tiles changed. Nevertheless, these are relatively small changes, as the maximum FAR change value highlights. The spatial distribution of changes can be seen in Figure 4. Particularly disturbing changes are observed in the Bródnowski corridor in the first period, where the changes seem to obscure direct flow at the peak of the corridor. A similar tendency can be seen in the Mokotowski corridor - although the potential to facilitate the air flow is still present, the strategic areas that enable the air flow are blocked. A detailed spatial analysis is provided by the $100 \mathrm{~m}$ grid analysis presented in the next section (See $100 \mathrm{~m}$ grid analysis).

A similar analysis was performed for the $100 \mathrm{~m}$ grid. The frequency distribution for all three periods is presented in Figure 5 and Table 3. 
According to the results, the biggest FAR index values occur in 2011, and the number of tiles with a value of zero decreased. It must be stressed here that these FAR results reach very high values due to the much smaller tile area, with areas ranging from $1 \mathrm{~m}^{2}$ to $1 \mathrm{ha}$. Therefore, the maximum possible value is 10 .

According to Table 4, the biggest change (in terms of area) between 1992 and 2002 occurred in the Jerozolimski corridor (almost $24 \%$ of its tiles changed their values). This is much lower in comparison to the $500 \mathrm{~m}$ tiles, but it detects subtler changes

Table 3. Frequency distribution of FAR values for $100 \mathrm{~m}$ grid

\begin{tabular}{|c|c|c|c|}
\hline Range values & $\mathbf{1 9 9 2}$ & $\mathbf{2 0 0 2}$ & $\mathbf{2 0 1 1}$ \\
\hline 0 & 8,244 & 8,017 & 7,500 \\
\hline $0.001-0.109$ & 944 & 992 & 1,166 \\
\hline $0.109-0.438$ & 394 & 480 & 668 \\
\hline $0.438-1.114$ & 96 & 153 & 248 \\
\hline $1.114-3.166$ & 23 & 55 & 105 \\
\hline $3.166-10.000$ & 6 & 10 & 20 \\
\hline
\end{tabular}

Source: own study and shows more precisely where the change occurred. Moreover, the maximum change within this corridor is the third biggest bigger values occur in the Mokotowski corridor and the Vistula river corridor. But when we consider the proportion of tiles that changed in these two corridors - $3 \%$ and $1.5 \%$, respectively this points to concentrated urban development. Nevertheless, the biggest change between 1992 and 2002 did indeed occur within the Mokotowski corridor - such a high value per tile indicates either a high rise building or a building occupying more than one tile. In comparison to the $500 \mathrm{~m}$ tiles, changes within rail corridors are much smaller - only $2.5 \%$ of tiles for the East corridor and $6.5 \%$ for the West corridor had changed by 2002.

The analysis of the next period (2002-2011) highlights that that the Jerozolimski corridor also changed the most (in terms of area); moreover, the maximum increase in FAR value also occurred in this corridor. The biggest mean value was again appointed to the Mokotowski corridor, even though only $12 \%$ of its tiles changed. The lowest maximum FAR change value was detected in the West Railway corridor, which is consistent with the conclusions of the $500 \mathrm{~m}$ grid analysis. The spatial distribution of the changes can be seen in Figure 6.

Both analyses provided satisfactory results, with the $500 \mathrm{~m}$ grid showing more general changes and detecting the main focal points, while the changes identified within the $100 \mathrm{~m}$ grid allowed them to be spatially allocated with much greater precision and correlated with the development of the particular district.

Table 4. Statistical FAR change between each period, Source: own study

\begin{tabular}{|c|c|c|c|c|c|c|}
\hline \multirow{2}{*}{$\begin{array}{c}\text { No. } \\
\text { (corridor) }\end{array}$} & \multicolumn{3}{|c|}{$1992-2002$} & \multicolumn{3}{|c|}{$2002-2011$} \\
\hline & $\%$ change & mean & $\max$ & $\%$ change & mean & $\max$ \\
\hline 1 & $1.58 \%$ & 0.611 & 6.049 & $4.79 \%$ & 0.159 & 3.423 \\
\hline 2 & $3.44 \%$ & 0.302 & 2.988 & $19.86 \%$ & 0.288 & 3.710 \\
\hline 3 & $2.58 \%$ & 0.060 & 0.148 & $6.13 \%$ & 0.058 & 0.153 \\
\hline 4 & $1.72 \%$ & 0.114 & 0.412 & $9.78 \%$ & 0.078 & 1.069 \\
\hline 5 & $1.52 \%$ & 0.075 & 0.257 & $14.74 \%$ & 0.091 & 1.000 \\
\hline 6 & $3.10 \%$ & 0.503 & 7.306 & $11.74 \%$ & 0.483 & 4.328 \\
\hline 7 & $23.47 \%$ & 0.463 & 3.397 & $30.13 \%$ & 0.420 & 5.567 \\
\hline 8 & $6.42 \%$ & 0.301 & 1.011 & $19.30 \%$ & 0.024 & 0.776 \\
\hline 9 & $3.82 \%$ & 0.577 & 2.695 & $8.64 \%$ & 0.084 & 1.192 \\
\hline
\end{tabular}
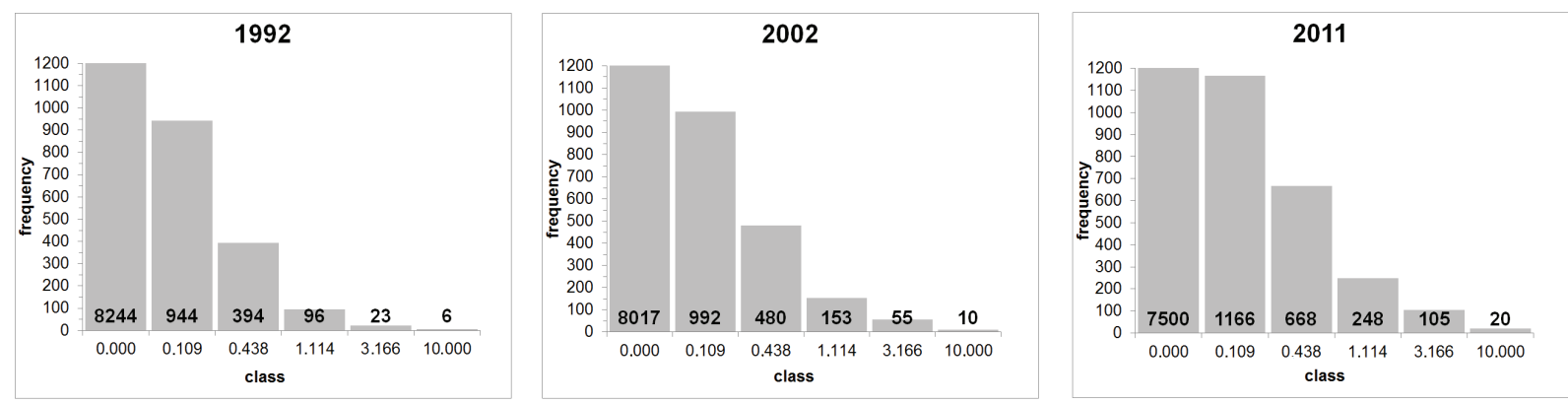

Figure 5. Frequency distribution of FAR values for $100 \mathrm{~m}$ grid, Source: own study 

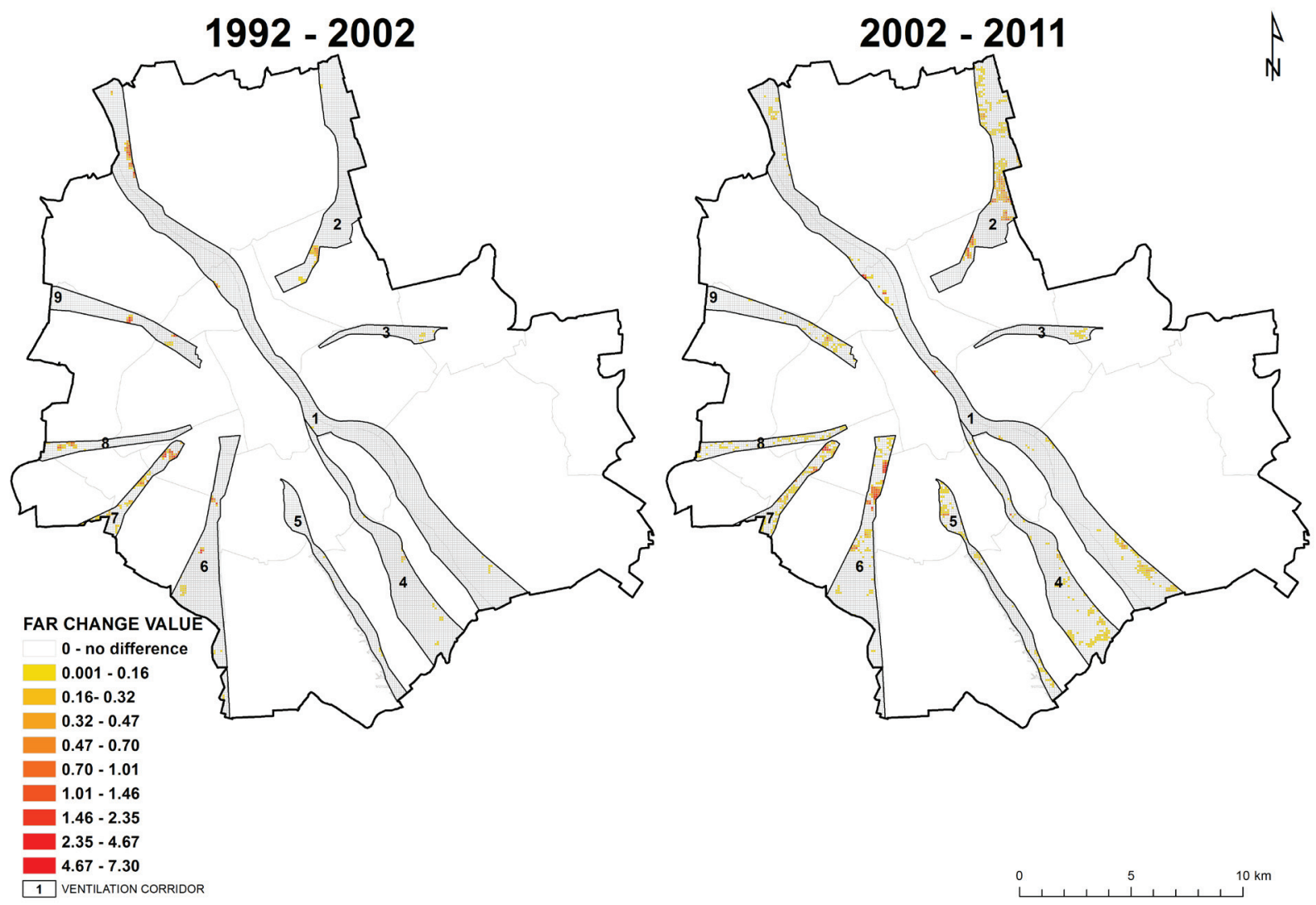

Figure 6. Spatial distribution of FAR changes in 1992 - 2002 and 2002 - 2011 for 100 m grid, Source: own study

Conclusions and Discussion

The aim of this research was to identify and analyse how urban development changed in ventilation corridors from 1992 to 2011. Numerous indicators were considered (Dabrowska-Milewska 2010a). The FAR index is (Śleszyński 2013) one of the best indicators to detect urban development within cities. It was chosen because, unlike WMNS, for example, it is not affected by frameworks or laws, so its values truly represent the characteristics of the area. The FAR index highlighted problematic areas within the ventilation corridors which have been substantially developed in the space of almost twenty years. Corridors such as Mokotowski or Bródnowski have been significantly built up. The changes seen on both the $500 \mathrm{~m}$ and $100 \mathrm{~m}$ grids within those two corridors point to some of the most intense cases of development, and given the fact that they are among the 'narrowest' in geometrical terms at the outlet to the city centre, air flow in these areas may be severely restricted. Also noteworthy is the fact that the Jerozolimski corridor where, according to the SUKiZ analysis done for SUKiZ, most of the air flows into the city, is also being gradually developed. According to Zawalich (2012), all the corridors are becoming progressively urbanized at the expense of agriculture areas which have been shown by research (Mayer, Beckröge \& Matzarakis 1994; Samimi \& Strobel 2003) to have "good" or "very good" potential for air flow. It also must not be overlooked that, even though a comprehensive study of conditions and directions for the spatial development of Warsaw clearly states maximum height and intensity (FAR index), the research has shown that in many cases these values are exceeded. This is partially caused by a lack of obligation to have local development plans (Zawalich 2012) and, in the case of Warsaw, the lengthy process of passing laws. This situation allows development to intensify, but even for the previously mentioned $23 \%$ of the city which is covered by binding development plans, the lack of cohesion between the rules of SUKiZ and their regulation is striking. There are therefore many cases of the abuse of building height regulations, which directly influences air flow.

It has been suggested that carrying out further studies on other indicators may result in a more comprehensive understanding of the urban processes occurring in the city, and could at the same time lead to the detection of areas that should be protected from development. Since no assessment was made of the functioning of the ventilation and air regeneration system (Zawalich 2012) during the preparation of the renewed version (in 2014) of the study of determinants and development trends for Warsaw (SUKiZ), it is also recommended that a study is conducted to determine how many of the ventilation corridors are actually still functioning, and to what extent. In our future research we plan to study methods for the delineation of urban ventilation corridors using the high resolution mapping of roughness parameters (Gál \& Unger 2009) in order to locate areas which may still aid the air restoration and exchange system and have not been included there yet. This research will also provide valuable information on the spatial configuration of development, which is crucial for ventilation. We also aim to investigate the performance analysis aided by remote sensing data by analysing the proportion of low roughness areas within the existing corridors. Unfortunately, one of Warsaw's huge assets might have been irretrievably disturbed by accelerated urban development, as this study concludes. 


\section{References}

Alanen, AR 1992, 'MODEL COMMUNITIES: THE GARDEN CITY MOVEMENT IN AUSTRALIA', Landscape Journal, vol. 11, no. 2, pp. 188-190. <10.3368/lj.11.2.188>.

Amati, M \& Yokohari, M 2006, 'Temporal changes and local variations in the functions of London's green belt', Landscape and urban planning, vol. 75 , no. 1, pp. 125-142. Available from: <http://www.sciencedirect.com/science/article/pii/ S0169204605000101>. [16 September 2014].

Blaschke, T 2010, 'Object based image analysis for remote sensing', ISPRS journal of photogrammetry and remote sensing, vol. 65, no. 1, pp. 2-16.

Bożętka, B 2014, 'Systemy zieleni miejskiej w Polsce-ewolucja i problemy kształtowania', Problemy Ekologii Krajobrazu, vol. 22, no. 22. Available from: <http://paek.ukw.edu.pl/pek/ index.php/PEK/article/view/2661>.[10 September 2014].

Buder, S 1990, Visionaries and planners: The Garden City movement and the modern community, Oxford University Press on Demand.

Culpin, EG 2015, The Garden City movement up-to-date, Routledge.

Dąbrowska-Milewska, G 2010a, 'Standardy urbanistyczne dla terenów mieszkaniowych-wybrane zagadnienia', Architecturae et Artibus, vol. 2, pp. 17-31. Available from: $<$ http://yadda.icm.edu.pl/baztech/element/bwmeta1. element.baztech-article-BPB1-0044-0003>. [28 November 2014].

Dąbrowska-Milewska, G 2010b, 'Standardy urbanistyczne jako narzędzie racjonalnej gospodarki terenami w mieście', Czasopismo Techniczne. Architektura, vol. 107, pp. 17-24. Available from: <http://yadda.icm.edu.pl/yadda/element/ bwmeta1.element.baztech-article-BGPK-3332-2945> [28 November 2014].

Davenport, A, Sue, C, Grimmond, B, Tim, O \& Wiering, J 2000, 'Estimating the roughness of cities and sheltered country', 12th Conference on Applied Climatology, pp. 96-99.

Drapella-Hermansdorfer, A 2005, 'Zielone osie i zielone pierścienie Berlina', Teka Komisji Architektury, Urbanistyki i Studiów Krajobrazowych, vol. 1. Available from: <https:// www.infona.pl/resource/bwmeta1.element.agro-9d0611cf8ed9-4c8e-bd59-0ce23ed2e7ce>.

Ebenezer, H 1902, Garden cities of tomorrow, London: Sonnenschein \& Co. Ltd.

Esri 2014, Data classification, Esri. Available from: <http:// resources.arcgis.com/en/help/main/10.2/index. html\#//003100000072000000>. [12 November 2014].

Feng, SU 2009, 'From technical rationality to policy attribute: Floor Area Ratio regulation in urban planning administration', City Planning Review, vol. 11, pp. 32-38.

Gál, T \& Unger, J 2009, 'Detection of ventilation paths using high-resolution roughness parameter mapping in a large urban area', Building and environment, vol. 44, no. 1 , pp. 198-206. Available from: <http://dx.doi.org/10.1016/j. buildenv.2008.02.008>

Gant, RL, Robinson, GM \& Fazal, S 2011, 'Land-use change in the 'edgelands': Policies and pressures in London's ruralurban fringe', Land Use Policy, vol. 28, no. 1, pp. 266-279. Available from: <http://www.sciencedirect.com/science/ article/pii/S0264837710000694>. [10 October 2014].

Gao, X, Asami, Y, Katsumata, W \& others 2006, 'Evaluating land-use restrictions concerning the floor area ratio of lots', Environment and Planning C, vol. 24, no. 4, p. 515. Available from: <http://sourcedb.cas.cn/sourcedb_igsnrr_cas/yw/ Iw/200906/P020090625745263593308.pdf>. [12 November 2014].
Ghiaus, C, Allard, F, Santamouris, M, Georgakis, C \& Nicol, F 2006, 'Urban environment influence on natural ventilation potential', Building and environment, vol. 41, no. 4, pp. 395-406.

Giedych, R 2005, 'Zarys prawnych przemian konkretyzacji pojęcia „tereny zieleni” w II połowie XX wieku w Polsce' in Tereny zieleni jako przedmiot planowania miejscowego (wybór tekstów) eds. R Giedych \& M Szumański, Wyd. SGGW, Warszawa, pp. 64-72.

Goldberg, V, Kurbjuhn, C \& Bernhofer, C 2013, ,How relevant is urban planning for the thermal comfort of pedestrians? Numerical case studies in two districts of the City of Dresden (Saxony/Germany)', Meteorologische Zeitschrift, vol. 22, no. 6, pp. 739-751. Available from: <http://dx.doi. org/10.1127/0941-2948/2013/0463>. [10 October 2014].

Gzell, S, Sołtys, M \& Tatarkiewicz-Nawrocka, A 2002, Idea miasta-ogrodu a tereny zieleni Warszawy, Warszawa: Oddział Warszawski SARP.

Hamdi, R \& Schayes, G 2008, ,Sensitivity study of the urban heat island intensity to urban characteristics', International Journal of Climatology, vol. 28, no. 7, pp. 973-982. Available from: <http://onlinelibrary.wiley.com/doi/10.1002/joc.1598/pdf>.

Han, S-G, Mun, S-H \& Huh, J-H 2007, 'Changes of the microclimate and building cooling load due to the green effect of a restored stream in Seoul, Korea'. International Building Performance Simulation Association Conference and Exhibition. Available from: <http://www.ibpsa.org/ proceedings/BS2007/p573_final.pdf>. [10 October 2014].

Handy, SL, Boarnet, MG, Ewing, R \& Killingsworth, RE 2002, 'How the built environment affects physical activity: views from urban planning', American Journal of Preventive Medicine, vol. 23, no. 2, pp. 64-73.

Heilig, GK 2012, 'World urbanization prospects the 2011 revision', United Nations, Department of Economic and Social Affairs (DESA), Population Division, Population Estimates and Projections Section, New York. Available from: <http:// esa.un.org/unpd/wpp/ppt/CSIS/WUP_2011_CSIS_4.pdf>. [07 August 2014].

Jankiewicz, A \& Porębska-Srebrna, J 2006, 'Tradycje urbanistyczne Warszawy' in Straty Warszawy 1939-1945, ed W Fałkowski, pp. 34-59.

Jiang, F, Liu, S, Yuan, H \& Zhang, Q 2007, ,Measuring urban sprawl in Beijing with geo-spatial indices', Journal of Geographical Sciences, vol. 17, no. 4, pp. 469-478.

Johnson, SP 1993, The Earth Summit: The United Nations Conference on Environment and Development (UNCED), Graham \& Trotman London.

Joshi, KK \& Kono, T 2009, 'Optimization of floor area ratio regulation in a growing city', Regional Science and Urban Economics, vol. 39, no. 4, pp. 502-511. Available from: <http://www.sciencedirect.com/science/article/pii/ S0166046209000155>. [28 November 2014].

Kono, T, Kaneko, T \& Morisugi, H 2010, 'Necessity of minimum floor area ratio regulation: a second-best policy', The Annals of Regional Science, vol. 44, no. 3, pp. 523-539. Available from: <http://link.springer.com/article/10.1007/s00168-0080269-0\#page-1>. [28 November 2014].

Królikowski, L \& Ostrowski, M 2009, Rozwój przestrzenny Warszawy, Mazowieckie Centrum Kultury i Sztuki, Warszawa.

Kronenberg, J \& Łódzki, U 2012, ,Usługi ekosystemów w miastach', Zrównoważony Rozwój-Zastosowania, vol. 3, pp. 14-28. Available from: <http://www.sendzimir.org.pl/images/ zrz 3 pl/01 uslugi ekosystemow w miastach.pdf $>$. [10 October 2014]. 
Mayer, H, Beckröge, W \& Matzarakis, A 1994, 'Bestimmung von stadtklimarelevanten Luftleitbahnen', UVP-report, vol. 5, no. 94, pp. 265-268. Available from: <www. researchgate.net/publication/233758609_Bestimmung_ von_stadtklimarelevanten_Luftleitbahnen/file/ d912f50b48bf562309.pdf>. [10 October 2014].

Mirzaei, PA \& Haghighat, F 2012, ,A procedure to quantify the impact of mitigation techniques on the urban ventilation", Building and environment, vol. 47, pp. 410-420.

$\mathrm{Ng}$, E 2006, 'Air ventilation assessment system for high density planning and design'. Proceedings of PLEA International Conference. Available from: <http://plea-arch. org/ARCHIVE/2006/Vol1/PLEA2006_PAPER642.pdf>. [07 August 2014].

$\mathrm{Ng}$, E 2009, 'Policies and technical guidelines for urban planning of high-density cities-air ventilation assessment (AVA) of Hong Kong', Building and environment, vol. 44, no. 7, pp. 1478-1488.

Rada m. st. Warszawy 1992, Uchwała Rady m. st. Warszawy nr XXXV/199/92 z dnia 28 września 1992 r. Miejscowy Plan Ogólny Zagospodarowania Przestrzennego m. st. Warszawy. XXXV/199/92. [12 November 2014].

Rizwan, AM, Dennis, LYC \& Chunho, LI 2008, 'A review on the generation, determination and mitigation of Urban Heat Island', Journal of Environmental Sciences, vol. 20, no. 1, pp. 120-128. Available from: <http://www.sciencedirect. com/science/article/pii/S1001074208600194>.

Samimi, C \& Strobel, BE 2003, 'Das Stadtklima von Erlangen unter Berücksichtigung kleinräumiger stadtklimatischer Strukturen', Mitteilungen der Fränkischen Geographischen Gesellschaft, vol. 50, no. 1, pp. 147-178. Available from: <fgg-erlangen.de/fgg/ojs/index.php/mfgg/article/ download/77/64>. [10 October 2014].

Śleszyński, P 2013, 'Propozycja kompleksowej koncepcji wskaźników zagospodarowania i ładu przestrzennego.' in Wskaźniki zagospodarowania $i$ ładu przestrzennego w gminach, ed P Śleszyński, pp. 176-232. Available from: <http://bkpzk.czasopisma.pan.pl/images/data/bkpzk/ wydania/No_252_2013/13\%20Rozdzia\%2011.pdf>. [28 November 2014].

Smętkowski, M 2009, 'Zróżnicowania społeczno-przestrzenne Warszawy-inercja czy metamorfoza struktury miasta? Sociospatial differentiation of Warsaw: inertia or metamorphosis of the city structure?', Przegląd geograficzny, vol. 81, no. 4, pp. 461-481.
Sokołowska-Moskwiak, J 2011, „Idea miasta-ogrodu”: na przykładach osiedli miast górnośląskich, Wydawnictwo Politechniki Śląskiej.

Solarek, K 2011, ,Współczesne koncepcje rozwoju miasta', Kwartalnik Architektury i Urbanistyki, vol. 56, pp. 51-71.

Suder, A \& Szymanowski, M 2014, ,Determination of ventilation channels In urban area: A case study of Wrocław (Poland)', Pure and Applied Geophysics, vol. 171, no. 6, pp. 965-975.

2010, Uchwała Rady m. st. Warszawy nr XCII/2689/2010 z dnia 7 października 2010 r. - Studium uwarunkowań i kierunków zagospodarowania przestrzennego m.st. Warszawy ze zmianami. SUKiZ. Available from: <http:// bip.warszawa.pl/NR/exeres/65234DA5-353F-4DAB-B0F68A7BCF587DA3,frameless.htm>. [12 November 2014].

2008, Uchwała Rady m. st. Warszawy nr XLII/1299/2008 z dnia 23 października 2008 r. - w sprawie uchwalenia miejscowego planu zagospodarowania przestrzennego rejonu pod Skocznią - część I. MPZP. Available from: <http://bip. warszawa.pl/NR/exeres/7F278AEF-0CFC-409F-BAE567531B899E1D,frameless.htm>. [06 December 2014].

United Nations 2007, ,Urbanization: A Majority in Cities', Population Fund 2007. Available from: <https://www.unfpa. org/pds/urbanization.htm>. [03 July 2014].

Wong, MS, Nichol, J \& Ng, E 2011, 'A study of the "wall effect" caused by proliferation of high-rise buildings using GIS techniques', Landscape and urban planning, vol. 102, no. 4, pp. 245-253.

Wurm, M, Taubenbock, H, Roth, A \& Dech, S 2009, 'Urban structuring using multisensoral remote sensing data: By the example of the German cities Cologne and Dresden'.Available from: <http://ieeexplore.ieee.org/document/5137555/>.

Zawalich, J 2012, Analiza zmian zagospodarowania obszaru klinów przewietrzających w Warszawie w latach 1992-2010, Bachelor Thesis, Warsaw, Poland. 